Primary research

\title{
A novel cell culture model for studying differentiation and apoptosis in the mouse mammary gland
} Katrina E Gordon, Bert Binas*, Rachel S Chapman ${ }^{\dagger}$, Kathreena M Kurian ${ }^{\dagger}$, Richard W E Clarkson ${ }^{\ddagger}$, A John Clark, E Birgitte Lane ${ }^{\S}$ and Christine J Watson ${ }^{\ddagger}$ Roslin Institute (Edinburgh), Roslin, UK, *Max Delbruck Center for Molecular Medicine, Berlin, Germany, ${ }^{+}$University of Edinburgh, Edinburgh, UK, "University of Cambridge, Cambridge, UK, and SUniversity of Dundee, Dundee, UK

\begin{abstract}
Background: This paper describes the derivation and characterization of a novel, conditionally immortal mammary epithelial cell line named KIM-2. These cells were derived from mid-pregnant mammary glands of a mouse harbouring one to two copies of a transgene comprised of the ovine $\beta$-lactoglobulin milk protein gene promoter, driving expression of a temperature-sensitive variant of simian virus-40 (SV40) large T antigen (T-Ag).

Results: KIM-2 cells have a characteristic luminal epithelial cell morphology and a stable, nontransformed phenotype at the semipermissive temperature of $37^{\circ} \mathrm{C}$. In contrast, at the permissive temperature of $33^{\circ} \mathrm{C}$ the cells have an elongated spindle-like morphology and become transformed after prolonged culture. Differentiation of $\mathrm{KIM}-2$ cells at $37^{\circ} \mathrm{C}$, in response to lactogenic hormones, results in the formation of polarized dome-like structures with tight junctions. This is accompanied by expression of the milk protein genes that encode $\beta$-casein and whey acidic protein (WAP), and activation of the prolactin signalling molecule, signal transducer and activator of transcription (STAT)5. Fully differentiated KIM-2 cultures at $37^{\circ} \mathrm{C}$ become dependent on lactogenic hormones for survival and undergo extensive apoptosis upon hormone withdrawal, as indicated by nuclear morphology and flow cytometric analysis. KIM-2 cells can be genetically modified by stable transfection and clonal lines isolated that retain the characteristics of untransfected cells.

Conclusion: KIM-2 cells are a valuable addition, therefore, to currently available lines of mammary epithelial cells. Their capacity for extensive differentiation in the absence of exogenously added basement membrane, and ability to undergo apoptosis in response to physiological signals will provide an invaluable model system for the study of signal transduction pathways and transcriptional regulatory mechanisms that control differentiation and involution in the mammary gland.
\end{abstract}

Keywords: apoptosis, differentiation, immortalization, mammary gland

\section{Introduction}

With each successive pregnancy, the mammary gland completes a cycle of growth, functional differentiation and involution. These processes are of great importance in biology in their own right, but they also provide an example of how proliferation, differentiation and apoptosis are

$\mathrm{BLG}=\beta$-lactoglobulin; $\mathrm{ECM}=$ extracellular matrix; EGF = epidermal growth factor; STAT = signal transducer and activator of transcription; $\mathrm{SV} 40=$ simian virus-40; $\mathrm{T}-\mathrm{Ag}=\mathrm{T}$ antigen; tsA58 $=$ temperature-sensitive variant of SV40 T-Ag; TBS = Tris-buffered saline; WAP = whey acidic protein. 
integrated into the organization of a complex three-dimensional tissue unit, whose function changes with time. The growth and development of ductal and alveolar structures during pregnancy is dependent on the interaction between the epithelial cells and stromal components of the mammary fat pad and requires the concerted actions of both peptide and steroid hormones, and cell-cell and cell-substratum interactions [1]. The necessity for these complex structural and hormonal interactions provide a challenge for the development of in vitro models for molecular studies that accurately mimic the differentiation and death of mammary epithelial cells.

A variety of mammary culture systems have been developed to facilitate studies on the regulation of gene transcription in the mammary gland. Whole organ and explant cultures have been of value in identifying the role of specific hormones in both the growth and differentiation of mammary tissue and the induction of milk protein gene expression [2]. These cultures have a limited lifespan, however, and are not useful for studies at the cellular level. Epithelial cells can be isolated from mammary tissue, maintained in culture and induced to differentiate with lactogenic hormones. The use of such primary cultures has demonstrated the importance of the cellular substratum in the differentiation process [3]. A major drawback of this system, in addition to the short lifespan of the cells, is the considerable amount of starting material required.

Spontaneously immortalized cell lines have arisen from prolonged culture of primary epithelial cells in low serum $(2 \%)$. Many of these established mammary epithelial cell lines have proved to be useful tools in molecular and biochemical studies. They include $\mathrm{EpH} 4$ cells [4] and the COMMA-1D cell line, one of the most widely used in vitro mammary systems, which exhibits mammary-specific functional differentiation when exposed to lactogenic hormones and extracellular matrix (ECM) [5]. Subclones of COMMA-1D include HC11 and CID9 [6,7]. HC11 cells have been widely used by us, and others, for studies on transcriptional regulation of milk protein gene expression [8,9], whereas CID9 cells have been extensively used to demonstrate the role of ECM in milk protein gene expression [7]. Furthermore, a pure epithelial population, SCp2, has been derived from CID9 [10]

In our laboratory, we are particularly interested in the signalling pathways that regulate gene expression in the differentiating and involuting mouse mammary gland. Despite the undoubted value of these culture systems, expression of transgenes in vivo does not always recapitulate expression observed in culture. This reflects the complex requirements for mammary epithelial cell differentiation and apoptosis. There is a need, therefore, for mammary epithelial cell lines that more accurately mimic the developing and involuting gland. Such cells should preferably be immortalized by a conditional (ie reversible) mechanism (in contrast to currently available lines) and be able to be genetically modified.

In order to achieve this, we adopted a modification of the procedure used to generate 'immortomouse', a line of transgenic mice that harbour a temperature-sensitive variant of an immortalizing gene, SV40 T-Ag, which is expressed from a constitutive promoter $\mathrm{H}_{2} \mathrm{~K}^{\mathrm{b}}$ [11]. Although the 'immortomouse' shows thymic hyperplasia, these transgenic mice undergo normal development and have proven to be a useful source of material to establish cell lines from tissues that have previously been refractory to culturing [12]. Our attempts to establish mammary epithelial lines from these mice were unsuccessful, however. This may be due to insufficient levels of $\mathrm{T}-\mathrm{Ag}$ being expressed in the mammary epithelial compartment to immortalize these cells or the presence of T-Ag in the other mammary compartments, thereby allowing the preferential immortalization of fibroblasts and other stromal cell types.

We therefore decided to refine this approach and target expression of the thermolabile T-Ag mutant specifically to the mammary epithelium of transgenic mice. Targeted expression can be achieved using either the mouse mammary tumour virus long terminal repeats or a milk protein gene promoter. We chose to use the promoter of the sheep milk protein gene encoding $\beta$-lactoglobulin (BLG), because BLG is less dependant than WAP on the transgene genomic integration site for its expression [13] BLG transgenes are expressed at low levels in the mammary glands of virgin mice, whereas expression is regulated during pregnancy and lactation with a similar expression profile to that of $\beta$-casein [14]. Therefore, it is likely that BLG expression occurs in dividing cells early in the differentiation pathway, a critical factor in establishing cultures from early stages of mammary gland development. Such cultures could contain epithelial stem cells because these are known to be distributed throughout the ductal tree [15]. We report herein the isolation and characterization of a stable line of mammary epithelial cells, named KIM-2, from mid-pregnant mammary glands of one line of mice with a low transgene copy number. Importantly, this cell line has a phenotypically normal epithelial morphology at $37^{\circ} \mathrm{C}$ and permits the analysis of the complex processes of differentiation and apoptosis in vitro. Moreover, we provide evidence that this line is susceptible to genetic manipulation, thus making available a resource for analysis of genetic function.

\section{Materials and methods \\ Construction of the transgene}

A fusion gene, consisting of $4.2 \mathrm{~kb}$ of the $5^{\prime}$-flanking promoter sequences, including the transcriptional start site, of the ovine BLG gene [16] and the temperature-sensitive variant of SV40 T-Ag (tsA58) coding sequences [11], was constructed. 
The $4.2 \mathrm{~kb}$ Sall/EcoRV fragment of the BLG promoter was isolated from pBJ39 (provided by Dr CBA Whitelaw) and subcloned into pBluescript vector (Stratagene Europe, Amsterdam, The Netherlands). A $3.9 \mathrm{~kb}$ Bgll fragment was isolated from pUC tsA58 [11], blunt ended using T4 DNA polymerase and digested with $\mathrm{BamHI}$, and a $2.7 \mathrm{~kb}$ fragment containing sequences encoding large and small $\mathrm{T}$ $\mathrm{Ag}$ was purified. This fragment was fused to the EcoRV site of the BLG promoter.

\section{Generation and identification of transgenic mice}

For microinjection the transgene was isolated free of vector sequences by double digestion with Sall and Xbal, and the transgene was purified by agarose gel electrophoresis. DNA $(1.5 \mathrm{ng} / \mu \mathrm{l})$ was microinjected into pronuclear mouse eggs (collected from C57BL/6 $\times$ CBA F1 mice after mating with $\mathrm{F} 1$ male studs) in order to generate transgenic mice. Lines were maintained by mating F1 mice that harboured the transgene, as determined by polymerase chain reaction analysis of tail biopsies [17]. All DNA manipulations were carried out using standard procedures [18].

\section{DNA analysis}

DNA was extracted from tail biopsies of 6-week-old mice, and analyzed by polymerase chain reaction and Southern blots. Genomic tail DNA was digested with an appropriate restriction enzyme, subjected to agarose gel electrophoresis and transferred to nylon membrane (Hybond N; Amersham Pharmacia Biotech, Uppsala, Sweden) [19]. Southern blots were hybridized [20] with a random oligoprimed probe (Prime-It II kit; Stratagene) [21] containing sequences from the probe 1 region of the transgene.

\section{RNA analysis}

RNA was extracted from tissue or from cultured cells using the acid guanidium thiocyanate-phenol chloroform method [22]. For northern blot analysis, $10 \mu \mathrm{g}$ total RNA was resolved on 1.0\% formaldehyde agarose gels, transferred to nylon membranes (Hybond $\mathrm{N}$; Amersham) and hybridized to [ $\left.{ }^{32} \mathrm{P}\right]$ dCTP-labelled random primed probes. Two probes were used for $\beta$-casein [23] and WAP [24].

\section{Explant cultures}

Mammary glands were aseptically removed from a midpregnant (day 14) transgenic mouse carrying the BLG/SV40 T-Ag construct and washed several times in dissection medium (HEPES-buffered M199 with gentamycin at $50 \mu \mathrm{g} / \mathrm{ml}$ and BRL's antibiotic/antimycotic solution; Gibco/BRL, Paisley, Scotland). The tissue was cut with scalpels into pieces of about $1 \mathrm{~mm}$ thickness in fresh dissection medium; seeded into collagen type Icoated flasks; and cultured at either the permissive temperature of $33^{\circ} \mathrm{C}$ or the semipermissive temperature of $37^{\circ} \mathrm{C}$ for about 2 weeks with daily medium changes $\left(1 \mathrm{ml} / 25 \mathrm{~cm}^{2}\right)$ in serum-free F12/Dulbecco's modified eagle's medium (1:1), supplemented with bovine insulin, ovine prolactin, cortisol, oestradiol (each $5 \mu \mathrm{g} / \mathrm{ml}$ ) and epidermal growth factor (EGF; $10 \mathrm{ng} / \mathrm{ml}$ ). During this period, an epithelial outgrowth formed around most explants, without fibroblast contamination. Explants were removed by simply shaking them off and washing the flask, and the culture was continued in F12/Dulbecco's modified eagle's medium (1:1) supplemented with $10 \%$ foetal calf serum, $5 \mu \mathrm{g} / \mathrm{ml}$ insulin, $10 \mathrm{ng} / \mathrm{ml}$ EGF, $5 \mu \mathrm{g} / \mathrm{ml}$ linoleic acid and $5 \mu \mathrm{g} / \mathrm{ml}$ gentamycin.

Primary cultures were passaged after several weeks when the circumference of the islands stopped growing. Cells were passaged as clumps of about five to 10 cells rather than as single cells, because this appeared to aid survival and maintenance of the epithelial phenotype. In order to produce clumps, trypsinization was shortened and performed at room temperature, the cells scraped off with a cell scraper, and the cell suspension handled with widebore pipettes. Cells are now routinely cultured at $37^{\circ} \mathrm{C}$ and passaged every three to four days at a 1:4 ratio onto collagen-coated flasks (growth on collagen once in every five passages is sufficient) and maintained for approximately 20 passages. No change in phenotype is observed with careful handling.

\section{Immunocytochemistry}

Cells were grown subconfluently on collagen-coated glass coverslips in four-well plates or on plastic slide flasks (Nunc/Nalge Europe, Hereford, UK). The cells were fixed in methanol:acetone for $10 \mathrm{~min}$, washed with Tris-buffered saline (TBS) $\mathrm{pH} 7.6$, blocked in TBS $+20 \%$ goat serum for $1 \mathrm{~h}$, and then immunostained with a panel of primary antibodies. Monoclonal antibodies to cytokeratin 18 and 19 were from EB Lane and SV40 T-Ag antibodies were kindly provided by Dr DP Lane (Department of Biochemistry, University of Dundee, Dundee, UK). Murine smooth muscle actin antibody was obtained from Sigma (A2547) as were E-cadherin (U 3254), laminin (L9393) and vimentin (V5255) (Sigma-Aldrich, Gillingham, Dorset, UK). Rat monoclonal antibody to zonula occluden-1 (MAB1520) was from Hemicon (Chemicon International Inc, Temecula, CA, USA). Antibody binding was visualized with fluorescein isothiocyanate (FITC)-labelled secondary antibodies (Sigma). Images were analyzed by fluorescence microscopy and, in some cases, phase and fluorescence images were subsequently merged.

\section{Electron microscopy}

Differentiated cells were trypsinized, centrifuged and fixed in $3 \%$ glutaraldehyde in $0.1 \mathrm{~mol} / \mathrm{l}$ sodium cacodylate $/ \mathrm{HCl}$ buffer of $\mathrm{pH} 7.2-7.4$ at $4^{\circ} \mathrm{C}$ for $48 \mathrm{~h}$. After washing with distilled water $\left(\mathrm{dH}_{2} \mathrm{O}\right)$ for $20 \mathrm{~min}$, the samples underwent secondary fixation in $1 \%$ osmium tetroxide in $\mathrm{dH}_{2} \mathrm{O}$ for $45 \mathrm{~min}$ at room temperature. Samples were then dehydrated with methylated spirits and absolute ethanol, 
before linking to propylene oxide for $10 \mathrm{~min}$ and impregnation in Emix resin (Fisons, Leicester, UK) overnight at room temperature. After polymerization for $18-24 \mathrm{~h}$ at $70^{\circ} \mathrm{C}$, 90-nm sections were mounted on 300-mesh copper grids and stained using the uranyl acetate/lead citrate method. Finally, sections were examined and photographs taken using a Jeol 100CXXII transmission electron microscope (Jeol Ltd, Welwyn Garden City, Herts, UK).

\section{Induction of milk protein gene expression}

Cells were grown on plastic-coated or collagen-coated flasks in growth medium until confluent. After 2 days, hormone induction media was then added, consisting of growth medium without EGF supplemented with dexamethasone and ovine prolactin. Cultures were induced for up to 12 days with media changes every 2 days.

\section{Western blot analysis}

In order to detect casein in total cell extracts, cells (area $8 \mathrm{~cm}^{2}$ ) were washed in phosphate-buffered saline and lysed directly in $0.5 \mathrm{ml}$ electrophoresis sample buffer $(0.125 \mathrm{~mol} / \mathrm{l}$ Tris $\mathrm{HCl} \mathrm{pH} 6.8,2 \%$ sodium dodecyl sulphate, $2 \% \beta$-2-mercaptoethanol, 10\% glycerol), shearing the DNA by repetitive pipetting, boiled for $10 \mathrm{~min}$ and stored at $-20^{\circ} \mathrm{C}$. The protein concentrations of the samples were determined using the BCA Protein Assay Reagent kit (Pierce and Warriner, Chester, UK).

One dimensional sodium dodecyl sulphate-polyacrylamide gel electrophoresis was performed as described by Laemmli [25] in 15\% polyacrylamide gels with a $3 \%$ stacking gel. Proteins were transferred from gels to nitrocellulose filters (Schleicher and Schuell, London, UK) at a current of $0.8 \mathrm{~mA} / \mathrm{cm}^{2}$ for $1 \mathrm{~h}$ using a semidry electroblotter [26]. After blocking nonspecific binding with $1 \%$ bovine serumn albumin in phosphate-buffered saline/Tween (0.1\%), the nitrocellulose was exposed to a polyclonal rabbit antimouse $\beta$-casein antibody diluted 1:10000 in blocking solution. Primary antibodies were visualized by peroxidase-conjugated anti-lg antibodies and ECL detection reagents (Amersham).

\section{Electrophoretic mobility shift assays}

Electrophoretic mobility shift assays were carried out using the highest affinity STAT binding site (STM) in the BLG promoter, as previously described [8]. Briefly, $4 \mu \mathrm{g}$ protein from nuclear extracts were incubated with ${ }^{32} \mathrm{P}$-labelled STM oligonucleotide in binding buffer, and analyzed on $6 \%$ native acrylamide gels, followed by autoradiography.

\section{Acridine orange staining and fluorescence microscopy}

KIM-2 cells were grown to confluency, washed in phosphate-buffered saline and incubated in Dulbecco's modified eagle's medium/F12 containing $3 \%$ serum (but no additional growth factors) for $48 \mathrm{~h}$. Cells $\left(1 \times 10^{6}\right)$ were fixed in $70 \%$ ethanol and stained with acridine orange $(5 \mu \mathrm{g} / \mathrm{ml}$; Molecular Probes Europe BV, Leiden, The
Netherlands). Classical features of apoptosis were identified with fluorescence microscopy.

\section{Flow cytometry and annexin $\mathbf{V}$ assay}

Undifferentiated cells

KIM- 2 cells were grown as above and $24 \mathrm{~h}$ later cells from the supernatant and monolayer were harvested. Cells $\left(1 \times 10^{5}\right)$ were stained with annexin $V$ and propidium iodide using the Apoptosis Detection Kit and following the manufacturer's instructions (R\&D Systems, Abingdon, Oxford, UK). Cells were analyzed by flow cytometry using a Coulter EPICS XL flow cytometer (Beckman Coulter, High Wycombe, Bucks, UK). Debris and clumps were gated out using forward and orthogonal light scatter. Green fluorescence ( $525 \mathrm{~nm}$; FITC annexin V) and red fluorescence $(613 \mathrm{~nm}$; propidium iodide) of 2000 cells was measured. The experiment was repeated three times.

\section{Differentiated cells}

KIM-2 cells were differentiated for 12 days with the lactogenic hormones insulin, dexamethasone and prolactin. Apoptosis was induced by removal of these hormones and measured $17 \mathrm{~h}$ later, as above.

\section{Results}

Generation of $\beta$-lactoglobulin-tsA58 transgenic mice

In order to direct expression of the conditional immortalizing gene to mammary epithelium, a hybrid construct containing the promoter of the sheep BLG milk protein gene, which is expressed predominantly in ductal and alveolar cells, was fused to the sequence encoding the temperature-sensitive early region variant of SV40 T antigen ( $\mathrm{T} \mathrm{Ag}$ ), tsA58. This construct (Fig. 1a) was used to generate transgenic mice by microinjection into fertilized oocytes from $(\mathrm{CBA} \times \mathrm{C} 57 \mathrm{BL} / 6) \mathrm{F} 1$ mice and in total 13 lines were generated. Several lines developed tumours in a number of anatomical sites as a consequence of ectopic expression of the transgene and leakiness of the temperature-sensitive mutation at the body temperature of the mice, and eight founders died before further analysis could be carried out. The severity of the phenotype in the surviving lines appeared to be copy number-related and was retained through subsequent generations of mice. The remaining five founders were used to derive transgenic lines. The number of copies of the transgene in each line was determined by Southern blotting (Fig. 1b) of DNA extracted from liver tissue and probed with a fragment of the BLG promoter and ranged from one to two copies (lines 2 and 8 ) to approximately 10 copies (line 13). One of the lowest copy number lines, line SV40-2, was used for the isolation of the $\mathrm{KIM}-2$ cell line described herein. This line does not display a tumour phenotype due to ectopic expression of T-Ag.

\section{Expression of the transgene in simian virus $\mathbf{4 0}$ line 2}

The level of expression of T-Ag in the mammary glands of line SV40-2 was determined. Low levels of tsA58 T-Ag 
Figure 1

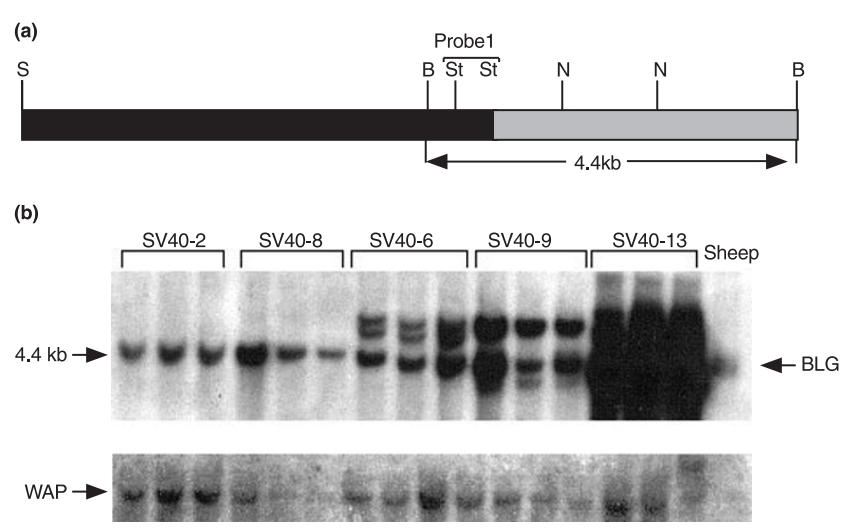

BLG-tsA58 transgenic mice. (a) Scheme of vector construct; $4.2 \mathrm{~kb}$ of the ovine BLG promoter including the noncoding exon 1 was fused to the 'enhancerless' SV40 T-Ag temperature sensitive mutant tsA58. The restriction sites shown are Sall (S), BamHI (B), Stul (St), and Ndel (N). The EcoRV and Bgll sites were destroyed during the construction of this vector. (b) The transgene copy number in the five surviving transgenic lines was estimated by Southern blotting. Digested genomic liver DNA $(10 \mu \mathrm{g})$ from three sisters in each of the lines was analyzed with sheep genomic liver DNA used as a single copy control. The blot was hybridized with probe 1 , and stripped and rehybridized with a WAP probe as a loading control.

mRNA were detected (data not shown). Protein was analyzed by western blotting in extracts from the lactating mammary glands of three sisters from this line (Fig. 2a). Levels of protein were consistent within this line. Expression of T-Ag did not perturb the normal development of the mammary gland and no mammary tumours were observed in this, or in any of the lines, despite T-Ag being present. This is shown in Figure 2b, which shows sections of tissue from virgin and day 11 lactation mammary glands of line SV40-2 and control F1 mice, showing the normal morphology. No lactational defects were apparent and these mice successfully nursed their offspring. This transgenic line has now been maintained for several years and mammary tumours have not been observed. This contrasts with the observation of tumour development in the WAP-T-Ag mice. This is probably a consequence of wildtype T-Ag being expressed in the WAP transgenics [27].

\section{Derivation of conditionally immortal cell lines}

Enrichment procedures have been described for partially purifying epithelial cells from the other types of cells that are present in the mammary gland [28]. These methods use enzymatic treatment and differential centrifugation to obtain a clean, fibroblast-free population of primary epithelial cells, and did not work well in our hands with the transgenic mice. We therefore developed a novel, simpler method that is based on the unpublished observation of one of us (BB) that, on a collagen-coated surface, fibroblast outgrowth from mammary explants requires the pres-
Figure 2

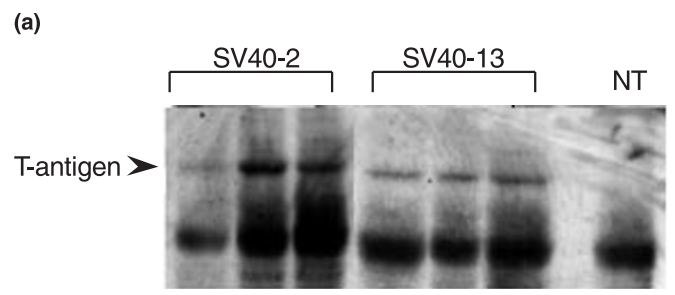

(b)

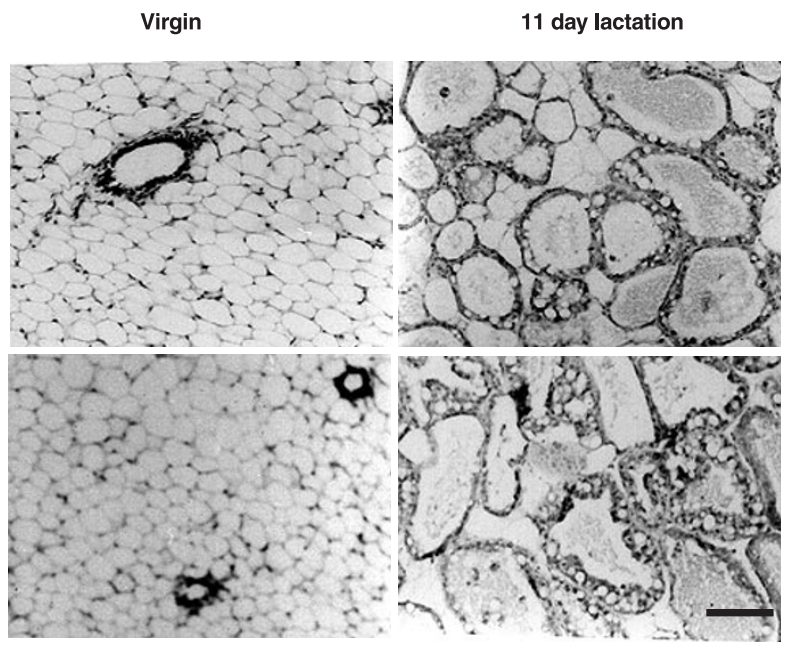

Expression of $\mathrm{T}-\mathrm{Ag}$ in the mammary glands of transgenic mice harbouring one to two copies (line SV40-2) or about 10 copies (line SV40-13) of the BLG-tsA58 transgene. (a) Protein extracts $(20 \mu \mathrm{g})$ were prepared from day 11 lactation mammary tissue from three agematched sisters from each line and a nontransgenic control mouse. The extracts were separated by sodium dodecyl sulphatepolyacrylamide gel electrophoresis, electroblotted onto nitrocellulose and probed with an anti-T-Ag antibody, DP-02. The nonspecific band is also seen in the control sample. (b) Morphological comparison of haematoxylin and eosin stained sections of virgin and 11-day lactation mammary glands from transgenic line SV40-2 (top) and a nontransgenic control (bottom). Histologically, the transgenic glands were indistinguishable from control glands. Scale bar $100 \mu \mathrm{m}$.

ence of serum, whereas epithelial cells grow out easily in a chemically defined medium. Initially, explant cultures were established from mammary glands excised from several lines of mice, with different transgene copy numbers. This procedure was most successful with tissue from the lowest copy number line SV40-2, and subsequent work was carried out with mammary tissue from this line. Mammary explant cultures were prepared by slicing the glands into $1 \mathrm{~mm}$ square pieces, seeding into collagen type I coated flasks and culturing for 2 weeks at the permissive $\left(33^{\circ} \mathrm{C}\right)$ and semipermissive temperature $\left(37^{\circ} \mathrm{C}\right)$ until outgrowths were well established (Fig. 3a). The explants were removed and the cells cultured until the islands stopped expanding in size. During this time period dome-like structures began to appear only in the cultures grown at $37^{\circ} \mathrm{C}$ (Fig. $3 b$ ). 
The primary cultures were routinely passaged as clumps of five to 10 cells, because single cell passaging results in the appearance of cells with a different morphology that was reminiscent of a fibroblastic phenotype. These cells are now routinely passaged every 3-4 days as clumps and divided $1: 3$ or $1: 4$. These cells, which we have designated $\mathrm{KIM}-2$, have been maintained in culture at $37^{\circ} \mathrm{C}$ for over 60 passages and have a stable phenotype both on plastic and collagen as assessed by immunocytochemistry.

\section{Characterization of the cell line}

Effects of growth temperature on morphology

$\mathrm{T}$-Ag immortalizes cells by complexing with the oncosuppressor proteins p53 and retinoblastoma protein [29]. It was expected that the temperature-sensitive variant of $\mathrm{T}$-Ag used to generate the transgenic animals would be nonfunctional at $37^{\circ} \mathrm{C}$. $\mathrm{KIM}-2$ cells can be isolated and grown at $37^{\circ} \mathrm{C}$ for over 60 passages, however, indicating that sufficient $\mathrm{T}-\mathrm{Ag}$ is functional at this temperature to effect immortalization (Fig. 4a). In contrast, cells isolated from mammary tissue at $33^{\circ} \mathrm{C}$ show an elongated spindlelike morphology (Fig. 4b), grow rapidly and immunostain with an antibody to a mesenchymal specific marker, vimentin (data not shown). These cells also form colonies in soft agar and may therefore be transformed; this is in contrast to the cells at $37^{\circ} \mathrm{C}$, which do not form colonies (Fig. 4c and d, and Table 1). A more accurate assessment of ability to form tumours requires growth in mice, and we are awaiting results of injecting these cell types into severe combined immunodeficiency mice. The temperature of $39^{\circ} \mathrm{C}$ is nonpermissive, and $\mathrm{KIM}-2$ cells grown at this temperature undergo a crisis and die after two or three passages. Because KIM-2 cells are phenotypically 'normal' at $37^{\circ} \mathrm{C}$ and grow rapidly, dividing approximately once every $24 \mathrm{~h}$, we selected this growth temperature for the experiments described in the present study, unless otherwise indicated.

\section{Expression of specific cell markers}

The characteristics of the KIM-2 cell line were established by immunocytochemistry. Antibody staining patterns suggest that these cultures are highly enriched for cells of luminal epithelial type, with over $95 \%$ of the cells staining strongly positive for keratin 18 (Fig. $5 d$ ), a luminal cell marker [30]. Approximately 5\% of the cells stained with either smooth muscle actin (Fig. 5c), which is characteristic of myoepithelial cells, or vimentin, a stromal and fibroblastic marker (Fig. 5e). Most cells show nuclear staining with a T-Ag-specific antibody (Fig. 5b). The keratin 14-specific antibody LL002 immunostains many cells. The epitope recognized by this antibody is frequently deregulated in cultured cells, however. The proportion of cells that stain for actin remains constant, even after multiple passages. These are probably of myoepithelial origin and derived from KIM-2 cells that have divided to give two types of cells (myoepithelial and luminal). This notion is
Figure 3
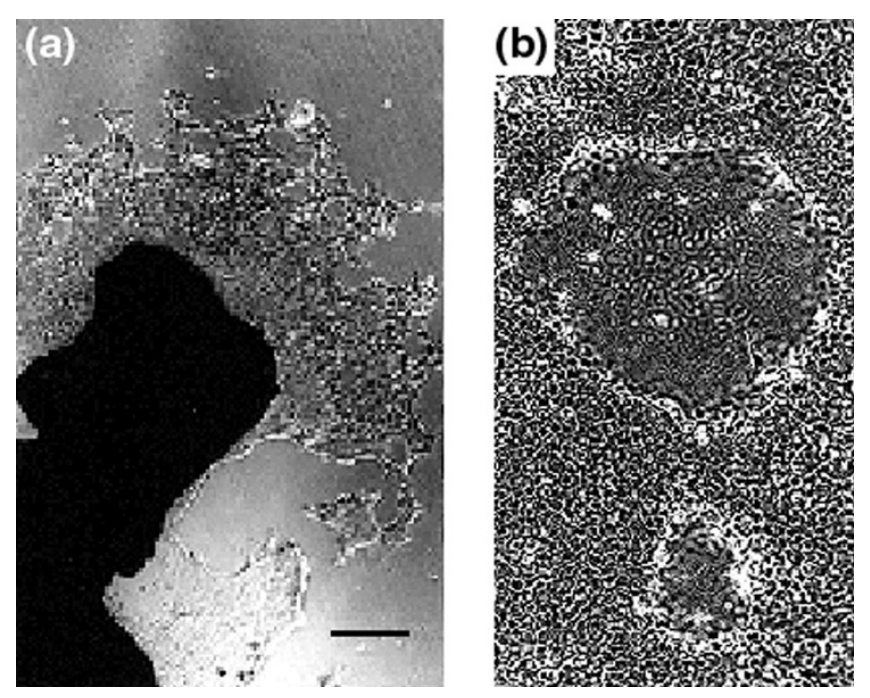

Derivation of primary cultures from mammary outgrowths. (a) Explants isolated from pregnant mammary tissue from transgenic line SV40-2 developed outgrowths after 2 weeks in culture at $37^{\circ} \mathrm{C}$ on type I collagen. The typical cobblestone morphology that is characteristic of epithelial cells was observed in these outgrowths by phase contrast microscopy. (b) After 14 days in culture the explants were removed and the primary cultures maintained for a further 7-14 days. Dome structures formed during this time period. Scale bar $250 \mu \mathrm{m}$.

supported from observations made on clonal derivatives (discussed below). Confluent cultures of KIM-2 cells deposit laminin, a component of the basement membrane, as shown by strong extracellular staining with an antibody to laminin (Fig. 6).

\section{Induction of differentiation}

Addition of lactogenic hormones to confluent cultures of KIM-2 cells resulted in a morphological change after approximately 2 days. Domes appeared in the confluent monolayer. These were substantial in size, usually containing upwards of 50 cells, and staining of these differentiated cultures with antibodies to $\alpha$-actin showed the presence of myoepithelial cells around the domes (Fig. 7c and d). This association of luminal and myoepithelial cells is reminiscent of alveolar structures. Immunocytochemistry with antibodies to the cell adhesion molecule E-cadherin (data not shown) and the junction protein zonula occluden-1 (Fig. 7e and $\mathrm{f}$ ), which is found at the apical and lateral plasma membrane boundaries between epithelial cells, showed that tight junctions are formed between the cells. Confluent undifferentiated monolayers of KIM-2 cells also form junctions as shown by the E-cadherin staining pattern (Fig. 7a and b). Using time lapse video microscopy, these domes were observed to pulsate, suggesting that transepithelial fluid transport is taking place into an expanding lumen and confirming that tight junctions have been formed (http://www.breast-cancer-research.com/content/2/3/v1). 

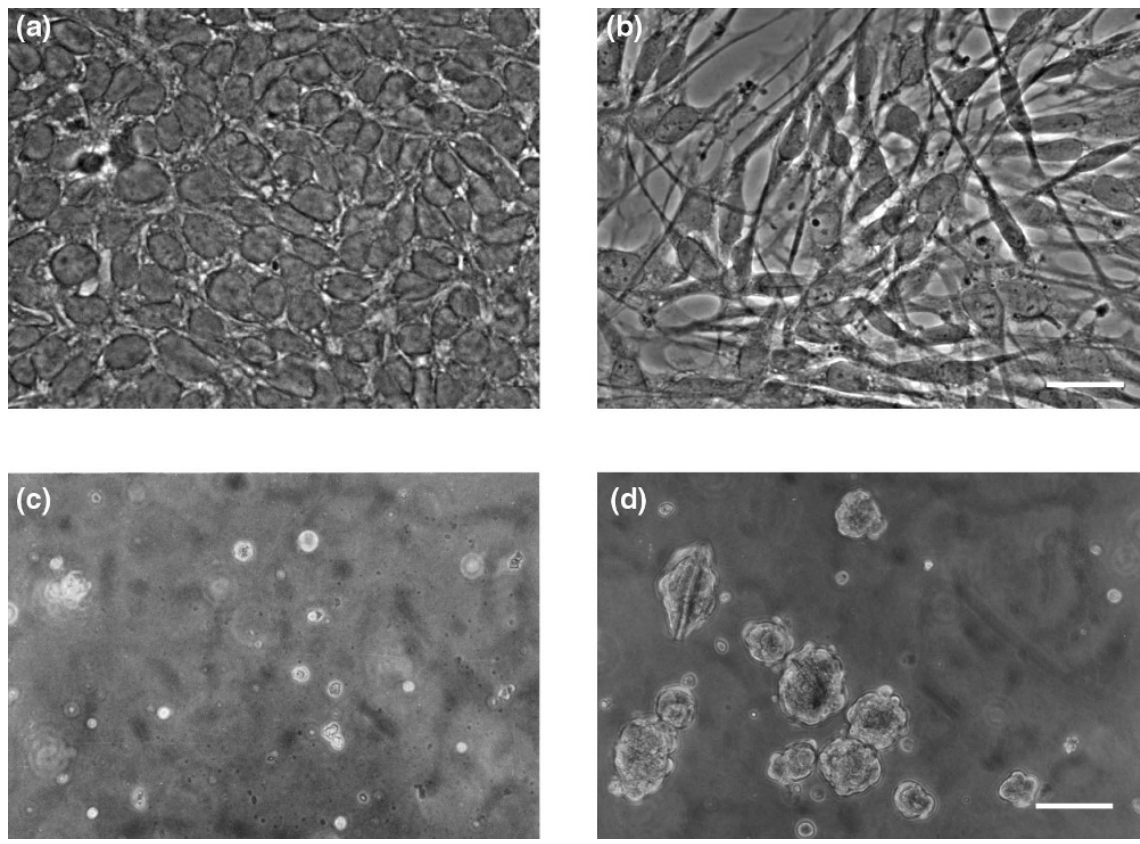

Effects of growth temperature on morphology and anchorage independent growth of KIM-2. (a) Cells isolated and grown at $37^{\circ} \mathrm{C}$ showing the typical cuboidal epithelial morphology. (b) Cells isolated and grown at $33^{\circ} \mathrm{C}$ have a spindle-like mesenchymal morphology. Scale bar for (a) and (b) $50 \mu \mathrm{m}$. (c) Cells, isolated and grown at $37^{\circ} \mathrm{C}$, seeded in soft agar and cultured for 12 days. Cells do not form colonies. (d) Cells, isolated and grown at $33^{\circ} \mathrm{C}$, seeded in soft agar and cultured for 12 days at $37^{\circ} \mathrm{C}$ showing the formation of colonies. Scale bar for (c) and (d) $10 \mu \mathrm{m}$.
Table 1

\section{Colony formation in soft agar by 'spindle' and 'normal' KIM-2} cells

\begin{tabular}{lcc}
\hline Cells seeded & 'Spindle' KIM-2 & 'Normal' KIM-2 \\
\hline $2 \times 10^{4}$ & $12.6 \pm 1.5$ & 0 \\
$1 \times 10^{4}$ & $11.0 \pm 2.0$ & 0 \\
$4 \times 10^{3}$ & $9.2 \pm 1.2$ & 0 \\
$2 \times 10^{3}$ & $8.4 \pm 2.0$ & 0 \\
$1 \times 10^{3}$ & $6.4 \pm 1.7$ & 0 \\
\hline
\end{tabular}

Cells were seeded at five different densities in soft agar and grown for 14 days. Colonies were defined as spherical growth of cells of $5 \mathrm{~mm}$ in diameter or more. Values shown are the means and standard deviations from triplicated experiments.

The differentiation of KIM-2 cells was further investigated using electron microscopy, which revealed the presence of milk protein and lipid droplets within the KIM-2 cells. Differentiated cells are polarized, microvilli being present on the apical surface (Fig. 8a). We also observed desmosomes between cells (Fig. 8b).

\section{Expression of differentiation markers}

Milk protein synthesis in vivo occurs within clusters of differentiated mammary epithelial cells in response to lactogenic hormones, ECM interactions and cell-cell interactions [1]. In cultures of KIM-2 cells grown at the semipermissive temperature of $37^{\circ} \mathrm{C}$ or the nonpermissive temperature of $39^{\circ} \mathrm{C}$, addition of lactogenic hormones induced partial differentiation as assessed by the synthesis of high levels of $\beta$-casein.

Figure 9a shows a western blot of induced and uninduced late passage cells (P31) grown on tissue culture plastic. For induction, the cells are grown to confluence, EGF removed for 2 days, and the lactogenic hormones dexamethasone, insulin and prolactin added for the time period indicated. There appear to be at least two different forms of cytoplasmic $\beta$-casein induced. One has an apparent molecular mass of $29 \mathrm{kDa}$ and there is also a lower molecular weight band, compared with $32 \mathrm{kDa}$ for the secreted protein found in milk. The discrepancy in size is probably due to differences in post-translational modifications between intracellular $\beta$-casein and the secreted form, and was also observed in $\mathrm{HC1} 1$ mammary cells (Fig. 9a). The level of $\beta$-casein induction is not affected by passage number or growth on collagen (data not shown). KIM-2 cells do secrete $\beta$-casein but at very low levels.

Other milk proteins that are expressed later in pregnancy, such as WAP, appear to require other factors in addition to lactogenic hormones for their expression. We were interested in investigating the possibility of WAP expression in KIM-2 cultures, because this is a more appropriate measure of differentiation status. Figure $9 b$ shows a time course of WAP mRNA induction with lactogenic hormones in KIM-2 cells grown on tissue culture plastic. Whereas $\beta$ casein expression was induced after 2 days, WAP expression was delayed until 4-8 days after hormone stimulation. These kinetics reflect the pattern of milk protein gene expression in the mammary gland, in which $\beta$-casein is 

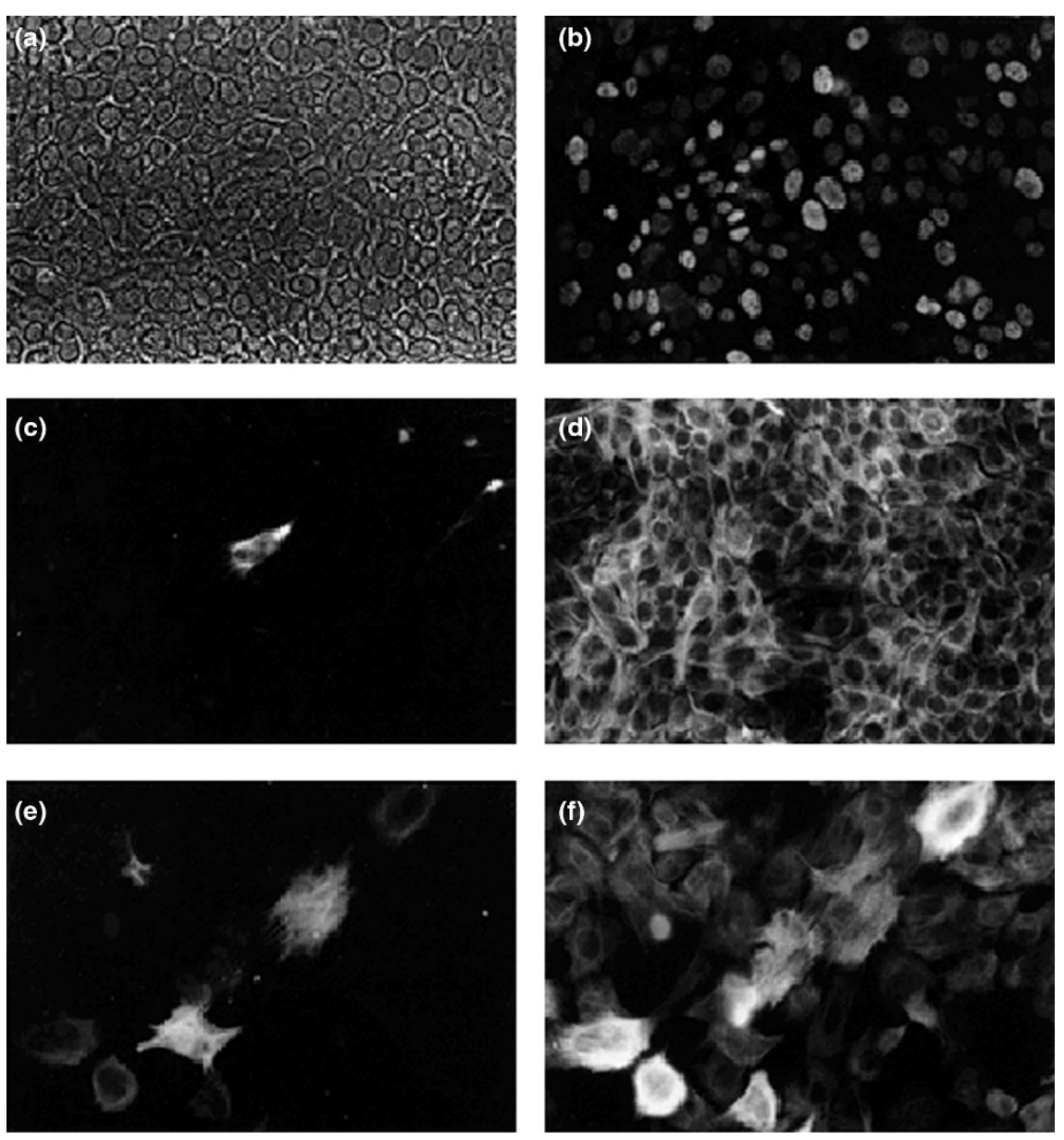

Immunocytochemical analysis of KIM-2 cells cultures at $37^{\circ} \mathrm{C}$. (a) Phase contrast. (b) The same field showing nuclear staining with a T-Ag-specific antibody (Pab 419). (c) Staining with a vimentin monoclonal antibody (Vim13.2) was detected in some fields. (d) Strong positive staining with a keratin 18-specific monoclonal antibody (LE61), a luminal epithelial marker. Scale bar for (a)-(d) $50 \mu \mathrm{m}$. (e) Staining with a smooth muscle actin monoclonal antibody, a myoepithelial marker. (f) Positive staining with a keratin 14-specific antibody (LLO02). The epitope recognized by this antibody is often deregulated in culture. Scale bar for (e) and (f) $25 \mu \mathrm{m}$. expressed from day 10 of pregnancy but WAP is not expressed until approximately 4 days later. Recently a STAT5a knockout has been generated that exhibits an impairment of lobuloaveolar development during pregnancy and an inability to lactate [31]. Although these mice show normal $\beta$-casein expression, the levels of WAP expression were reduced considerably. Clearly the induction of WAP expression has more complex requirements that may include contacts with the ECM, expression of specific receptors and/or expression of differentiation-related genes. It is possible that prolonged stimulation of $\mathrm{KIM}-2$ cells with lactogenic hormones induces these changes.

\section{Signal transduction}

STAT5 is a signalling molecule for prolactin and may also be a survival factor for differentiated mammary epithelia. We therefore investigated the activation of STAT5 in KIM-2 cells stimulated with prolactin. Figure 10a shows a time-course of STAT5 induction as assayed by electrophoretic mobility shift assay. Detectable amounts of STAT5 were observed within 5 min of prolactin addition, reaching a peak between 30 and 60 min. Interestingly, the response to prolactin was biphasic. Following the initial peak at $30 \mathrm{~min}$, the response declined to almost basal levels before again reaching a peak at about $24 \mathrm{~h}$ that was then sustained for at least 8 days. This kinetic profile is not surprising, because high STAT5 levels are maintained in the mammary gland during lactation in the continued presence of prolactin. The immediate downregulation could be in response to phosphatases, which have been shown to be associated with cytokine receptors and may interact directly with STAT factors [32], or to the upregulation of other genes such as members of the suppressor of cytokine signalling (SOCS) family of negative regulators [33]. It will be interesting to determine the mechanism of this early regulatory response, which is a feature of STAT activation in other cell systems. The prolonged activation of STAT5 could reflect the need for a survival factor for differentiated cells and may be associated with withdrawal from the cell cycle. Antibodies that specifically recognize either STAT5a or STAT5b supershift the complex observed, suggesting that both forms of STAT5 are activated in KIM-2 cells (data not shown). This parallels observations in the mammary gland [34,35]. 
Figure 6

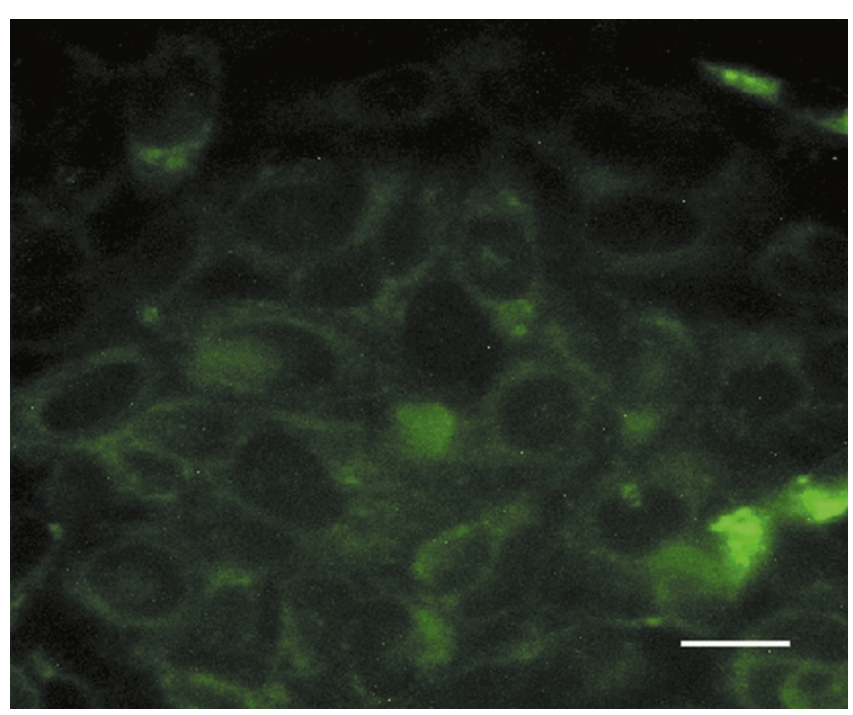

Deposition of laminin by KIM-2 cells. A confluent monolayer of undifferentiated KIM-2 cells was stained with an antibody to laminin and detected by FITC-conjugated secondary antibody. Control slides with secondary antibody alone were completely blank. Scale bar $25 \mu \mathrm{m}$.

These characteristics suggest that $\mathrm{KIM}-2$ cells are an excellent model for mammary epithelial cell differentiation. In order to use this model to investigate the molecular mechanisms of signal transduction and gene expression in mammary cells, it is essential that these cells can be genetically modified. This has been achieved using a variety of transfection methods to mediate DNA transfer, although retroviral transduction is the most efficient. We have now isolated a number of clonal cell lines from KIM-2 cells transfected with green fluorescent protein constructs. These clonal lines are morphologically similar to KIM-2 cells and can be induced to form domes and differentiate [36]. A similar number of cells staining for $\alpha$-actin are observed in cultures of clonal lines, suggesting that KIM-2 cells are progenitor cells that can differentiate into myoepithelial or luminal epithelial types. Similar observations have been made for human breast cells [37].

\section{Induction of apoptosis in KIM-2 cells}

The mammary gland undergoes a process of remodelling after weaning in which the lobuloalveolar compartment is removed by apoptosis. In order to investigate the molecular basis of involution, it would be invaluable to have available a mammary epithelial cell line that can be induced to undergo apoptosis in response to physiological signals. We therefore tested a variety of growth conditions for their ability to induce apoptosis and found that undifferentiated KIM-2 cells cultured in reduced serum (3\%), with no added growth factors, die over a period of $24-48 \mathrm{~h}$.
Apoptosis was classically defined by the morphological changes that occur, including cell shrinkage, chromatin condensation and nuclear fragmentation [38]. These changes were visualized using acridine orange staining and fluorescence microscopy and are obvious in dying KIM-2 cells compared with healthy cultures where the cells have diffusely stained nuclei (Fig. 11).

Although this method allows a clear definition of apoptosis, it does not allow rapid and precise quantification of the process. One of the early changes that occur during apoptosis is the translocation of phosphatidylserine from the inner to the outer surface of the plasma membrane, presumably enabling the recognition of apoptotic cells by phagocytes [39]. This can be detected with annexin $V$ and quantified by flow cytometry. Figure $12 \mathrm{a}$ shows the flow cytometric analysis of control cells and cells induced to die $24 \mathrm{~h}$ after treatment; the percentage of cells in each of the four populations is shown. A small number of control cells stain with propidium iodide and annexin $\mathrm{V}$, probably as a consequence of membrane disruption during the harvesting procedure. An approximately eightfold increase in apoptosis was seen when KIM-2 cells were cultured in reduced serum with no additional growth factors. An increase in the number of cells that stained with both propidium iodide and annexin $\mathrm{V}$ was also observed, probably reflecting the late loss of membrane integrity that occurs in cells in culture when they are not removed by phagocytosis.

Apoptosis of differentiated KIM-2 cultures would be a more useful model of apoptosis during involution in vivo. We therefore induced apoptosis in differentiated KIM-2 cultures by removal of the lactogenic hormones prolactin, dexamethasone and insulin. Approximately 30\% of the cells underwent apoptosis after $17 \mathrm{~h}$ in the absence of these hormones (Fig. 12b). Control cells exhibit an apparently high level of apoptosis. This is a consequence of membrane disruption during the harvesting procedure, because these differentiated cells are tightly associated and difficult to disperse. Interestingly, in reduced serum (3\%) differentiated KIM-2 cells, in contrast to undifferentiated cells, did not die, suggesting that at least one of the lactogenic hormones is a survival factor for functionally differentiated mammary epithelial cells (Fig. 12b).

Time-lapse video microscopy of differentiated cultures, induced to die by hormone withdrawal, shows cells detaching from the dish and the eventual collapse of the domes (http://www.breast-cancer-research.com/content/2/3/v2).

The ease of inducing and quantitatively measuring apoptosis, coupled with the ability to manipulate KIM-2 cells genetically, should allow a detailed analysis of the early transcription events that regulate this process. The relevance of these genes to involution in the mammary gland can then be investigated. 

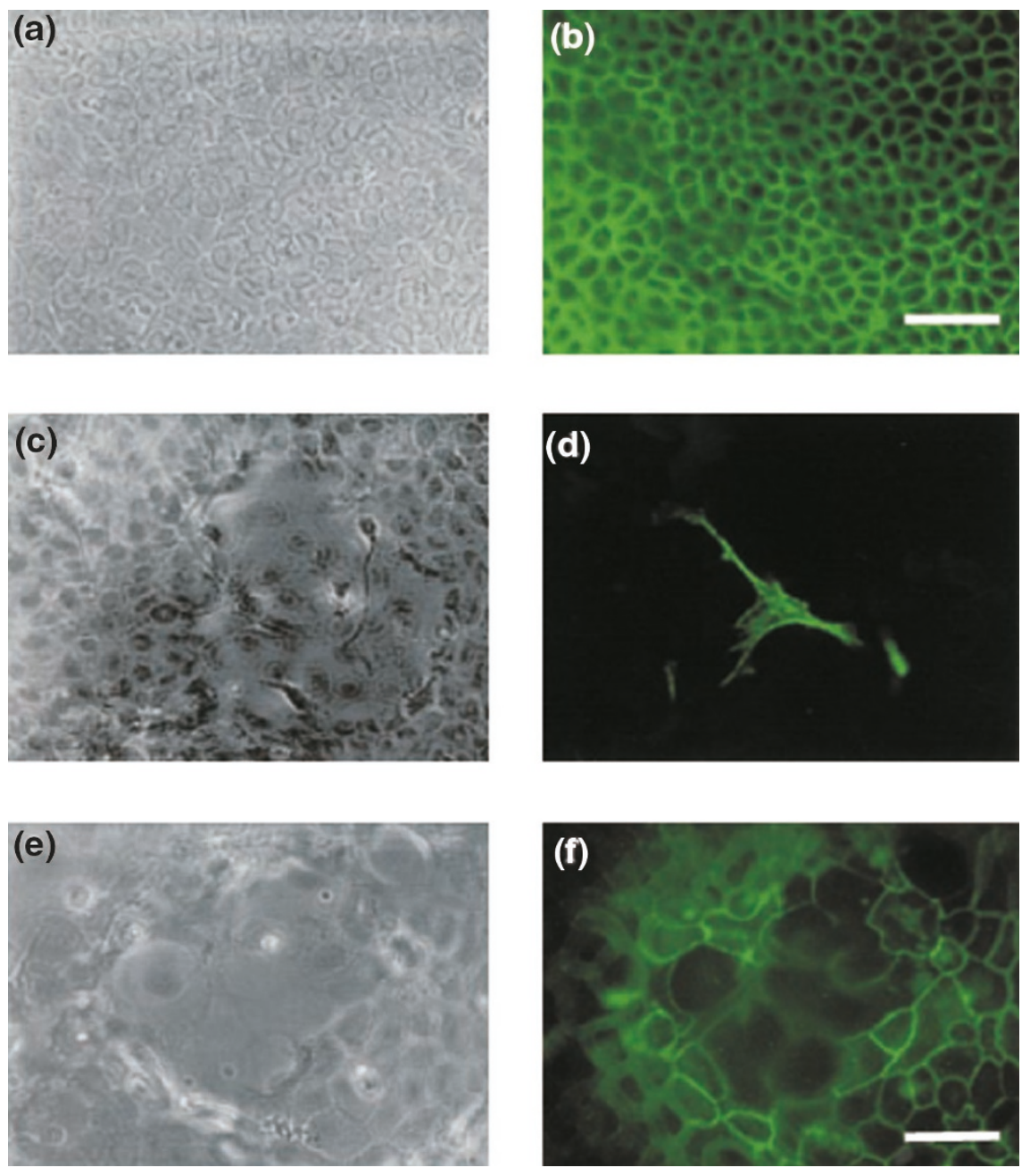

Analysis of junction formation and differentiation of KIM-2 cells. (a) Phase contrast. (b) Detection of E-cadherin on surface of confluent monolayer of cells. Scale bar for (a) and (b) $50 \mu \mathrm{m}$. (c) Phase contrast of differentiated cells and (d) detection of myoepithelial cell on surface of dome with an antibody to smooth muscle $\alpha$-actin. Scale bar for (c) and (d) $50 \mu \mathrm{m}$. (e) Phase contrast of dome and (f) detection of tight junctions with antibody to zonula occluden-1. Scale bar for (e) and (f) $25 \mu \mathrm{m}$.

\section{Discussion}

The morphological changes that take place during a mammary gland developmental cycle have been well defined and characterized. However, the molecular mechanisms that are involved in the regulation of lobuloalveolar development during pregnancy and the removal of this compartment by apoptosis during involution are just beginning to be understood, partly because it has been difficult to obtain a suitable in vitro model system that accurately mimics mammary gland development. The aim of this work was to establish a mammary cell culture system that would be of value in biochemical and functional studies of the control of differentiation and apoptosis.

To achieve this aim, we adapted the approach developed by Jat et al [11] and derived a mammary-specific 'immortomouse' using the BLG milk protein milk promoter to drive expression of a temperature-sensitive allelle of SV40 large T-Ag. We also developed a novel culture system to enrich for luminal epithelial cells. These procedures allowed us to successfully derive a novel line of conditionally immortal mammary epithelial cells. These cells retain a stable phenotype that is characteristic of luminal epithelial cells at the normal growth temperature of $37^{\circ} \mathrm{C}$ as evidenced by immunocytochemical analysis using lineage specific markers. At $39^{\circ} \mathrm{C}$, the cells are not immortal and die within a few passages.

The growth characteristics of the KIM-2 cell strain were dramatically influenced by the culture temperature. Isolating epithelial cells at the permissive temperature of $33^{\circ} \mathrm{C}$ resulted in apparently transformed cells with a spindle morphology that form colonies in soft agar. This phenotype cannot be reverted by switching up the growth temperature to $37^{\circ} \mathrm{C}$. Switching down the growth temperature from $37^{\circ} \mathrm{C}$ to $33^{\circ} \mathrm{C}$, however, caused a gradual change in morphology from cuboidal epithelial to a more fibroblastic appearance over a period of several weeks. Immunocytochemical analysis of these cells revealed the presence of vimentin and $\alpha$-actin, along with keratin 18, suggesting 
Figure 8
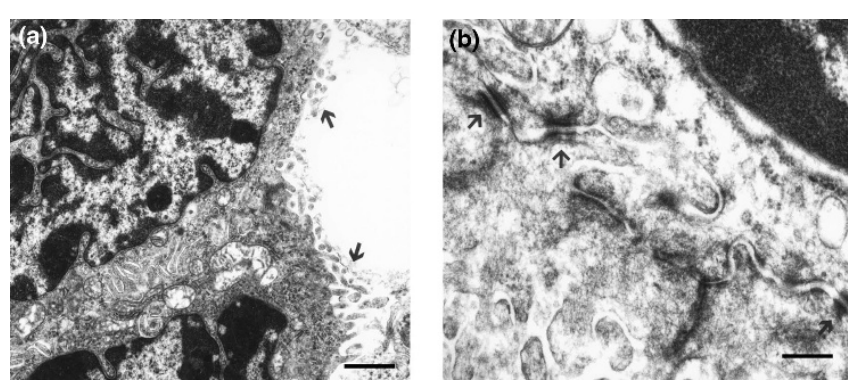

Electron microscopy of differentiated KIM-2 cells. (a) Microvilli (arrowed) on the apical surface of cells and showing the interdigitated cytoplasm at the boundary between two cells. Scale bar $2 \mu \mathrm{m}$.

(b) Higher magnification showing the presence of desmosomes (arrowed). Scale bar $0.5 \mu \mathrm{m}$.

that conversion of the epithelial cells to a more fibroblastic or myoepithelial cell type had taken place. After a switch down in growth temperature from $37^{\circ} \mathrm{C}$ to $33^{\circ} \mathrm{C}$ for $48 \mathrm{~h}$ or more, the phenotypic switch became irreversible.

Of the 13 transgenic founder lines generated, the lowest copy number line SV40-2 was used as the source of mammary cells for these experiments. Surprisingly, expression of T-Ag RNA in the mammary glands of line SV40-2 mice was barely detectable by northern blot analysis (data not shown), although T-Ag could be detected by western blot (Fig. 2a), suggesting that the BLG promoter is dysregulated when fused to $\mathrm{T}-\mathrm{Ag}$ sequences. The reason for this is not clear but it may be a consequence of the integration site of the transgene and the lack of sequences from within the body of the BLG gene and/or in its 3 '-terminal end, which confer integration site independence [40]. Whatever the mechanism, the low levels of T-Ag messenger RNA encode sufficient protein for the immortalizing role of SV40 $\mathrm{T}-\mathrm{Ag}$, which is readily detectable in the nuclei of cells in culture (Fig. 5b). The low expression of T-Ag may explain our observation that no mammary tumours were found, even in the animals that developed tumours at ectopic sites. Ectopic expression of BLG transgenes has been observed previously and high levels of T-Ag mRNA were found in the tumours.

KIM-2 cells have a characteristic epithelial morphology. Immunocytochemical analysis demonstrated the presence of the luminal-specific marker keratin 18 in the majority of the cells and the absence of fibroblastic markers. Some myoepithelial cells were observed that were characterized by their elongated morphology and positive staining with antibodies to $\alpha$-actin. These cells were frequently found to be associated with the dome-like structures that formed in response to lactogenic hormone induction (Fig. 7) and may suggest that both cell types are necessary for the formation of these alveolar-like structures. We have derived a sub-
Figure 9

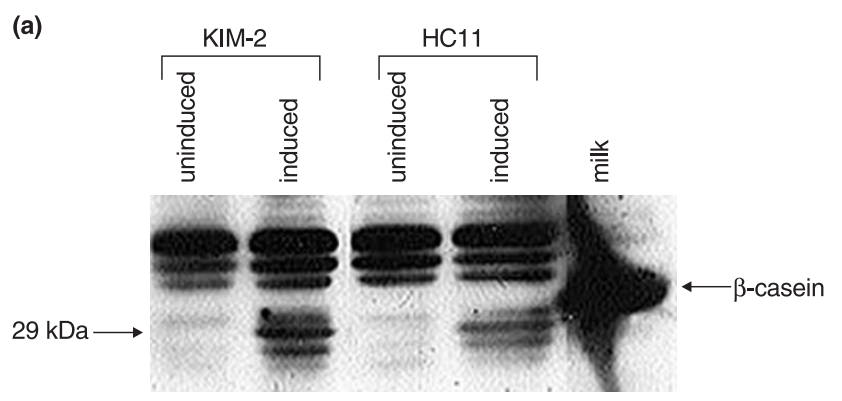

(b)

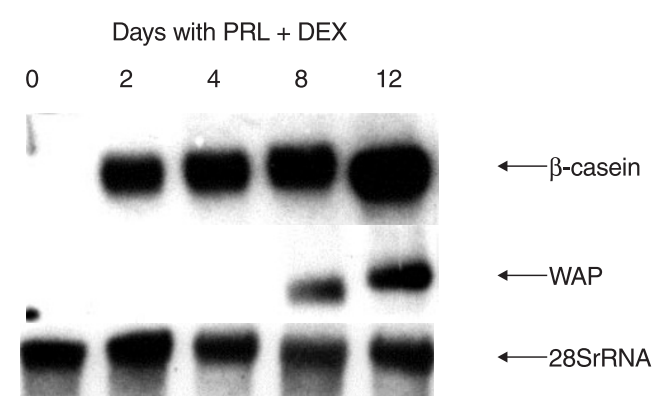

Analysis of the differentiation capacity of KIM-2 and $\mathrm{HC} 11$ cells in response to lactogenic hormones on tissue culture plastic.

(a) Endogenous $\beta$-casein expression was analyzed in $\mathrm{KIM}-2$ and $\mathrm{HC} 11$ cells by western blot. Total cell lysates $(20 \mu \mathrm{g})$ were prepared from $\mathrm{KIM}-2$ cells or $\mathrm{HC} 11$ cells grown to confluence and induced with the lactogenic hormone cocktail of insulin, prolactin and dexamethasone for 4 days at $37^{\circ} \mathrm{C}$. Uninduced cells were grown to confluence in growth medium. A defatted mouse milk sample was used as a positive control for the murine $\beta$-casein polyclonal antibody (diluted 1:10 000). Intracellular $\beta$-casein appeared to be a doublet at approximately $29 \mathrm{kDa}$ in extracts from both cell lines, whereas a $32 \mathrm{kDa}$ secreted $\beta$-casein was detected in defatted milk. This size discrepancy can be accounted for by differences in phosphorylation states between intracellular and secreted forms of the protein. (b) WAP and $\beta$-casein expression were analyzed in KIM-2 cells by northern blot. Total RNA $(20 \mu \mathrm{g})$ was prepared from $\mathrm{KIM}-2$ cells grown to confluence at $37^{\circ} \mathrm{C}$ and harvested or induced with lactogenic hormones for the time period indicated. WAP mRNA was detected after 8 days exposure to lactogenic hormones. Figures are representative of three separate experiments, although induction of WAP expression was variable and occurred between 4 and 8 days after hormone treatment in different experiments.

stantial number of clonal lines from KIM-2 cells by transfection of selectable markers. These clonal derivatives also form dome structures and have a myoepithelial component suggesting that KIM-2 cells are a progenitor of both luminal and myoepithelial cells. Selective growth of these cell types [37] would provide a resource for the discovery of genes, using microarray technology, which are expressed specifically in one type of cell [41]. The exciting possibility that KIM-2 cells may be stem cells will be tested by their ability to repopulate a cleared mammary fat pad. If this is successful, genetically modified KIM-2 cells could be used to generate transgenic mammary glands [42]. 


\section{Figure 10}

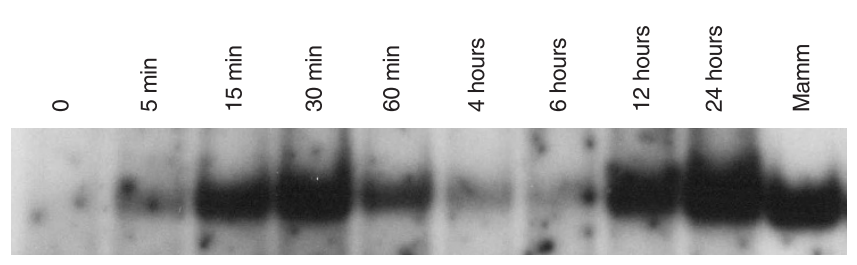

Analysis of STAT5 activation by electrophoretic mobility shift assay in $\mathrm{KIM}-2$ cells stimulated with prolactin. Nuclear extracts were prepared from confluent KIM-2 cultures stimulated with prolactin, in the absence of EGF, for the time periods indicated. The track labelled Mamm is an extract from a day 2 lactation mouse mammary gland. Uninduced control cells were maintained in growth medium. Extracts $(4 \mu \mathrm{g}$ protein) were incubated with a radioactively labelled DNA probe containing the highest affinity ovine BLG STAT5 binding site [34] and complexes resolved on a nondenaturing $6 \%$ acrylamide gel. A representative of more than three experiments is shown.

The formation of cell-cell contacts was investigated by using antibodies to E-cadherin and zonula occluden-1 and by electron microscopy. Staining at cell contacts was observed for both E-cadherin and zonula occluden-1 (Fig. 7). The formation of structures resembling desmosomes was seen by electron microscopy, and the presence of microvilli on the apical surfaces of cell clusters suggests that the cells are polarized, which is a feature of alveolar cells in vivo. The synthesis and deposition of laminin by KIM-2 cells that we have observed may be essential for polarization in addition to cell-cell contact.

Polarization is also essential for the expression and secretion of milk proteins. We showed previously that growth on ECM (principally laminin) is necessary for the activation of STAT5 in response to prolactin in primary cultures [43]. It is likely, therefore, that the synthesis and deposition of laminin by KIM-2 cells provides the necessary extracellular signals for the activation of sufficient levels of STAT5 for induction of full differentiation. Indeed, it has been shown that the binding of STAT5 to the WAP promoter is essential for maximal expression [44]. It is likely that STAT5 is a
Figure 12
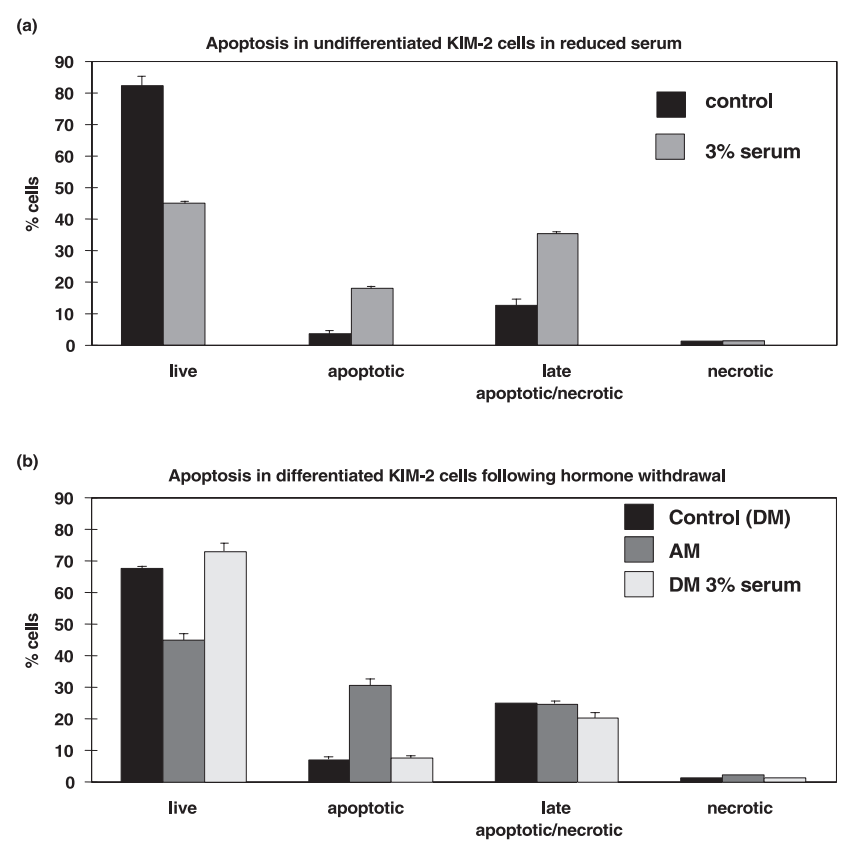

Analysis of apoptosis by flow cytometry. (a) Cells were induced to undergo apoptosis by culturing in reduced serum (3\%) and the absence of additional growth factors for $24 \mathrm{~h}$. (b) Cells that had been cultured in differentiation medium (DM) for 12 days were induced to undergo apoptosis by removal of prolactin, insulin and dexamethasone (AM) for $17 \mathrm{~h}$. Control and dying cells were stained with annexin $\mathrm{V}$ and propidium iodide $(\mathrm{PI})$ and analyzed by flow cytometry. PI enters only cells with damaged membranes (late apoptosis or necrosis). Four populations of cells were identified: live (no stain), apoptotic (annexin V only), late apoptotic/necrotic (annexin $\mathrm{V}+\mathrm{Pl}$ ) and necrotic (PI) only. The percentage of cells in each population is shown as the mean of three experiments with the standard error of the mean.

survival factor for differentiated mammary epithelial cells, and this is currently being tested.

Undifferentiated KIM-2 cells can be induced to undergo apoptosis by the removal of growth factors in serum. Apoptosis is extensive and rapid with approximately $30 \%$ of undifferentiated cells dying after 24 h. More relevantly,

\section{Figure 11}
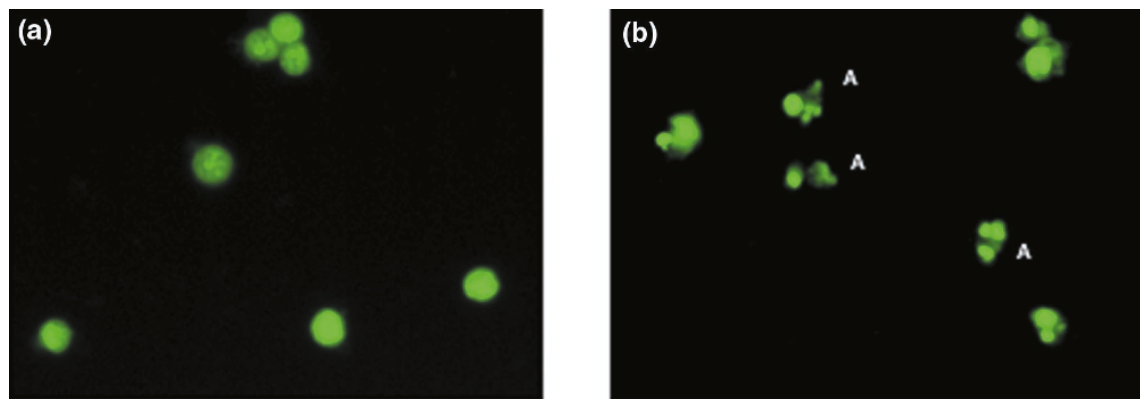

Induction of apoptosis in KIM-2 cells. KIM-2 cells were cultured in reduced serum and the absence of additional growth factors for $24 \mathrm{~h}$, inducing apoptosis in approximately $40 \%$ of the cells. (a) Control and (b) dying KIM-2 cells were stained with acridine orange and visualized by fluorescence microscopy. Examples of cells exhibiting classical apoptotic morphology are indicated by the letter ' $A$ '. 
apoptosis can be induced in fully differentiated KIM-2 cells after removal of lactogenic hormones. Apoptosis has been studied in a variety of mouse mammary epithelial cell lines. KIM-2 cells are an important addition to this repertoire, because they exhibit different features. Differentiated cells do not require addition of exogenous basement membrane for survival (unlike CID9 cells, which die with delayed kinetics in the absence of basement membrane [45]) and have wild-type p53 (unlike $\mathrm{HC} 11$ cells, which harbour mutant p53 allelles [46]). Apoptosis in individual cells can be observed using fluorescence microscopy, and this can be coupled with detection of other markers such as green fluorescent protein reporter constructs [36]. Thus, the KIM-2 cell line will be of value in future studies on early transcription events in the apoptotic process.

The low copy number line of BLG/SV40tsT mice can be crossed with other mice that harbouring either transgenes or gene deletions, thereby allowing the isolation of mammary cell lines from interesting mouse mutants. This will allow us to establish cell lines from knockout mice and should be invaluable for transfection studies that are aimed at identifying functional domains and interactions between signalling pathways in mammary epithelium.

\section{Acknowledgements}

We thank the staff of the SAU for excellent husbandry, Roberta Wallace for microinjections, Frank Donnelly for help with electron microscopy, Tom Burdon for advice and comments, Andrew Wyllie for his enthusiastic support and Mina Bissell for encouragement and inspiration. This work was supported by the BBSRC Stem Cell Molecular Biology Programme, The Cancer Research Campaign, the Cunningham Trust, the Home Office and the Association for International Cancer Research. Kathreena Kurian is an Edinburgh University Medical Faculty Research Fellow.

\section{References}

1. Topper YJ, Freeman CS: Multiple hormone interactions in the developmental biology of the mammary gland. Physiol Rev 1980, 60:1049-1056

2. Levine JF, Stockdale FE: Cell-cell interactions promote mammary epithelial cell differentiation. J Cell Biol 1985, 100:1415-1422.

3. Li M, Aggeler J, Farson DA, et al: Influence of reconstituted basement membrane and its components on casein expression and secretion in mouse mammary epithelial cells. Proc Natl Acad Sci USA 1987, 84:136-140.

4. Reichman E, Ball R, Groner B, Friis RR: New mammary epithelial and fibroblastic cell clones in coculture form structures competent to differentiate functionally. J Cell Bio/ 1989, 108:1127-1138.

5. Danielson KG, Oborn CJ, Durban EM, Butel JS, Medina D: Epithelial mouse mammary cell line exhibiting normal morphogenesis in vivo and functional differentiation in vitro. Proc Natl Acad Sci USA 1984, 81:3756-3760.

6. Ball RK, Friis RR, Schonenberg CA, Doppler W, Groner B: Prolactin regulation of $\beta$-casein gene expression and of a cytosolic $120 \mathrm{kD}$ protein in a cloned mouse mammary epithelial cell line. EMBO J 1988, 7:2089-2095.

7. Schmidhauser C, Bissell MJ, Myers CA, Casperson GF: Extracellular matrix and hormones transcriptionally regulate bovine $\beta$-casein $5^{\prime}$ sequences in stably transfected mouse mammary cells. Proc Nat Acad Sci USA 1990, 87:9118-9122.

8. Burdon,TG, Maitland, KA, Clark, AJ, Wallace, R, Watson, CJ: Regulation of the sheep $\beta$-lactoglobulin gene by lactogenic hormones is mediated by a transcription factor that binds an interferon- $\gamma$ activation site-related element. Mol Endocrinol 1994, 8:1528-1536.
9. Doppler W, Groner B, Ball R: Prolactin and glucocorticoid hormones synergistically induce expression of transfected rat $\beta$ casein gene promoter constructs in a mammary epithelial cell line. Proc Natl Acad Sci USA 1989, 86:104-108.

10. Desprez PY, Roskelley C, Campisi J, Bissell MJ: Suppression of mammary epithelial cell differentiation by the helix-loop-helix protein ID-1. Mol Cell Differ 1995, 1:99-110.

11. Jat PS, Noble MD, Ataliotis $P$, et al: Direct derivation of conditionally immortal cell lines from an H-2kb-tsA58 mouse. Proc Natl Acad Sci USA 1991, 88:5096-5100.

12. Whitehead RH, VanEden PE, Noble MD, Ataliotis P, Jat PS: Establishment of conditionally immortalised epithelial cell lines from both colon and small intestine of adult $\mathrm{H}-2 \mathrm{~K}^{\mathrm{b}}$-tsA58 transgenic mice. Proc Natl Acad Sci USA 1993, 90:587-591.

13. Whitelaw CBA, Harris S, McClenaghan M, Simons JP, Clark AJ: Position independent expression of the ovine $\beta$-lactoglobulin gene in transgenic mice. Biochem J 1992, 286:31-39.

14. Harris S, McClenaghan M, Simons JP, Ali S, Clark AJ: Developmental regulation of the sheep $\beta$-lactoglobulin gene. Dev Genet 1991, 12:299-307.

15. Kordon EC, Smith GH: An entire functional mammary gland may comprise the progeny from a single cell. Development 1998, 125:1921-1930.

16. Archibald AL, McClenaghan M, Hornsey V, Simons JP, Clark AJ: High level expression of biologically active human $\alpha 1$-antitrypsin in the milk of transgenic mice. Proc Natl Acad Sci USA 1990, 87:51785182.

17. Simons JP, McClenaghan M, Clark AJ: Alterations in the quality of milk by expression of sheep $\beta$-lactoglobulin in transgenic mouse. Nature 1987, 328:530-532.

18. Sambrook J, Fritsch EF, Maniatis T: Molecular Cloning: A Laboratory Manual, 2nd ed. New York: Cold Spring Harbor Laboratory Press; 1989.

19. Southern EM: Detection of specific sequences among DNA fragments separated by gel electrophoresis. J Mol Biol 1975, 98:503517.

20. Church GM, Gilbert W: Genomic sequencing. Proc Natl Acad Sci USA 1984, 81:1991-1995.

21. Feinberg AP, Vogelstein B: A technique for radiolabelling DNA restriction endonuclease fragments to high specific activity. Addendum Anal Biochem 1984, 137:6-13.

22. Chomcyzynski P, Saachi N: Single-step method of RNA isolation by guanidium thiocyanate-phenol-chlorofrom extraction. Anal Biochem 1987, 62:156-159.

23. Rosen JM: Milk protein gene structure and expression. In: The Mammary Gland: Development, Function and Regulation. Edited by Neville MC, Daniel CW. New York: Plenum; 1987:301-322.

24. Henninghausen L, Sippel AE: Characterisation and cloning of the mRNAs specific for lactating mouse mammary gland. Eur $J$ Biochem 1982, 125:131-141.

25. Laemmli UK: Cleavage of structural proteins during assembly of the head of bacteriophage T4. Nature 1970, 227:680-685.

26. Khyse-Andersen J: Electroblotting of multiple gels: a simple apparatus without buffer tank for rapid transfer of proteins from polyacrylamide to nitrocellulose. J Biochem Biophys Meth 1984, 10: 203-209.

27. Ewald D, Li MG, Efrat $S$, et al: Time-sensitive reversal of hyperplasia in transgenic mice expressing SV40 T antigen. Science 1996, 273:1384-1386.

28. Barcellos-Hoff MH, Aggeler J, Ram TG, Bissell MJ: Functional differentiation and alveolar morphogenesis of primary mammary cultures on reconstituted basement membrane. Development 1989 , 105:223-235.

29. Bartek J, Vojtesek B, Grand RJA, Gallimore PH, Lane DP: Cellular localisation and $\mathrm{T}$-antigen binding of the retinoblastoma protein. Oncogene 1992, 7:101-108.

30. Lane EB: Monoclonal antibodies provide specific intramolecular markers for the study of epithelial tonofilament organisation. J Cell Biol 1982, 92:665-673.

31. Liu X, Robinson GW, Wagner K-U, et al: STAT5a is mandatory for adult mammary development and lactogenesis. Genes Dev 1997, 11:179-186.

32. Darnell JE: STATs and gene regulation. Science 1997, 277:16301635.

33. Starr R, Hilton D: A family of cytokine-inducible inhibitors of signalling. Nature 1997, 387:917-921.

34. Philp JAC, Burdon TG, Watson CJ: Differential activation of STATs 3 and 5 during mammary gland development. FEBS Lett 1996, 396:77-80. 
35. Liu X, Robinson GW, Henninghausen L: Activation of STAT5a and STAT5b by tyrosine phosphorylation is tightly linked to mammary gland differentiation. Mol Endocrinol 1996, 10:1496-1506.

36. Clarkson RWE, Watson CJ: NFKB and apoptosis in differentiated mammary epithelial cells. J Mam Gland Biol Neoplasia 1999, 4: 165-176.

37. Pechoux C, Gudjonsson T, RonnovJessen L, Bissell MJ, Petersen OW: Human mammary luminal epithelial cells contain progenitors to myoepithelial cells. Dev Biol 1999, 206:88-99.

38. Wyllie AH: What is apoptosis? Histopathology 1986, 10:995-998.

39. Martin SJ, Reutelingsperger CPM, McGahon AJ, et al: Early redistribution of plasma-membrane phosphatidylserine is a general feature of apoptosis regardless of the initiating stimulus-inhibition by overexpression of Bcl-2 and Abl. J Exp Med 1995, 182: 1545-1556.

40. WebsterJ, Donofrio G, Wallace R, Clark AJ, Whitelaw CBA: Intronic sequences modulate the sensitivity of $\beta$-lactoglobulin transgenes to position effects. Gene 1997, 193:239-243.

41. Kurian KM, Watson CJ, Wyllie AH: DNA chip technology. J Pathol 1999, 187:267-271.

42. Bradbury JM, Edwards PAW, Niemeyer CC, Dale TC: Wnt-4 expression induces a pregnancy-like growth pattern in reconstituted mammary glands in virgin mice. Dev Biol 1995, 170:553-563.

43. Streuli $\mathrm{CH}$, Edwards GM, Delcommenne M, et al: STAT5 as a target for regulation by extracellular matrix. J Biol Chem 1995, 270: 21639-21644.

44. Li S, Rosen JM: Nuclear factor I and mammary gland factor (STAT5) play a critical role in regulating rat whey acidic protein gene expression in transgenic mice. Mol Cell Biol 1995, 15:20632070.

45. Boudreau N, Werb Z, Bissell MJ: Suppression of apoptosis by basement membrane requires three-dimensional tissue organisation and withdrawal from the cell cycle. Proc Natl Acad Sci USA 1996, 93:3509-3513.

46. Merlo GR, Venesio T, Taverna, D, et al: Growth suppression of normal mammary epithelial cells by wild-type p53. Oncogene 1994, 9:443-453.

Authors' affiliations: Katrina E Gordon and A John Clark [Division of Molecular Biology, Roslin Institute (Edinburgh), Roslin, UK], Bert Binas (Hypertension Research, Max Delbruck Center for Molecular Medicine, Berlin, Germany), Rachel S Chapman and Kathreena M Kurian (Sir Alastair Currie CRC Laboratories, Molecular Medicine Centre, University of Edinburgh, Western General Hospital, Edinburgh, UK), Richard W E Clarkson and Christine J Watson (Department of Pathology, University of Cambridge, Cambridge, UK) and E Birgitte Lane (Department of Anatomy, University of Dundee, Dundee, UK)

Correspondence: Christine J Watson, Department of Pathology, University of Cambridge, Tennis Court Road, Cambridge, CB2 1OP, UK. Tel: +44 (0)1223 333725; fax: +44 (0) 1223333346 ; e-mail: cjw53@mole.bio.cam.ac.uk 